\title{
Translating Traditional Thai Poetry into an English Verse Form
}

\author{
Gritiya Rattanakantadilok
}

\begin{abstract}
The original text is an epic poetry in Thai and this paper analyzes one segment that is rendered into an English verse form from the translation entitled The Tale of Khun Chang Khun Phaen by Baker and Pasuk (2010/2012). The translators sought a form that fills a parallel function within the poetic tradition of the target language, which is blank verse, the form appropriate to epic in English. Because of the differences in phonological rules, morphological patterns and syntactic rules between Thai and English, the translators have to find what is possible in the target language and meanings have to be sacrificed in verse translation.
\end{abstract}

Index Terms-Poetry translation, verse translation, poetic tradition, epic poetry.

\section{INTRODUCTION}

Sepha rueang Khun Chang Khun Phaen is translated by Baker and Pasuk into prose, only a handful of segments are rendered into poetic forms, many different poetic forms as the translators see fit. In the preface to the translation, Baker and Pasuk [1] state that Sepha rueang Khun Chang Khun Phaen was composed in verse and they translated the opening and closing paragraphs in an English-language approximation of the metrical form as a sample. This reveals the translators' attempts to retain the source text (ST)'s layout in the target text (TT) and their attempts to yield effects, particularly phonic and graphic, on the TT readers are not restricted to the opening and closing paragraphs of the story. Certain parts of the story are also rendered in verse and different approach(es) to verse translation were taken. The segment to be analyzed is the second segment that is rendered into a poetic form which appears after the opening paragraph. The translation of this segment does not mimic the layout and rhyming pattern of the ST as the opening and closing paragraphs. The ST's layout and its important poetic devices will be compared with the TT's layout and poetic devices. Sepha rueang Khun Chang Khun Phaen follows the pattern called klon pat and this meter will be explained through the stanzas of what I shall call the second segment throughout this paper.

Manuscript received June 15, 2015; revised September 18, 2015. This work was supported by School of Languages, Cultures and Societies, University of Leeds and the Humanity and Social Science Scholarship of Thailand, Office of the Higher Education Commission, Ministry of Education.

Gritiya Rattanakantadilok is with the School of Languages, Cultures and Societies, University of Leeds, UK and also with the Faculty of Liberal Arts, Prince of Songkla University, Thailand (e-mail: mlgr@leeds.ac.uk, gritiya.r@psu.ac.th).

\section{SOURCE TEXT}

This segment is about the khwan-calling ceremony for Khun Phaen (who is called Phlai Ngam as a child). It is performed when Khun Phaen, the leading male character, is one-month old. The words roek, khwan, and phuang kaeo lae phuang thong, considered to be culturally specific items, remain in their transliterated forms in the 'literal translation' column because of their complex nature. The translated choices opted for will be discussed in detail when an analysis is carried out in terms of cultural and semantic matrix.

The word pat means eight, which is the desirable number of syllables in each hemistich. I translate klon pat as 'eight-syllabled poem'.

The original layout of the second segment is as following:

si si wan ni roek di laeo choen khwan phlai kaeo ya pai $\underline{n a i}$

khwan ma yu su kai hai sabai jai chom chang ma kha thai thang ngoen thong

khwan oei jao ma thoet pho ma ya thiao ka-ken tra-wen thong

ma chom phuang kaeo lae phuang thong khao khong luea lai sabai jai

There are four wak (วรรค; hemistich) forming one bot or kha-na (บท; คณะ; stanza). The first hemistich is called wak salap (วรรคสลับ), the second wak rap (วรรครับ), the third wak rong (วรรครอง) and the fourth wak song (วรรคส่ง). Wak salap and wak rap (the first two hemistiches) are called bat ek (บาทเอก; the first line) and wak rong and wak song (the third and fourth hemistiches) are called bat tho (บาทโn; the second line). Bat ek and bat tho form one bot or one kha-na (stanza). There are two stanzas in the second segment. To show a required rhythmic pattern in eight-syllabled poem, the rhymes are underlined and the rhymes between stanzas are underlined twice in the transliterated version.

Nim [2] specifies the desirable number of syllables in each hemistich at between eight or nine and the desirable rhymes are as shown in Fig. 1:

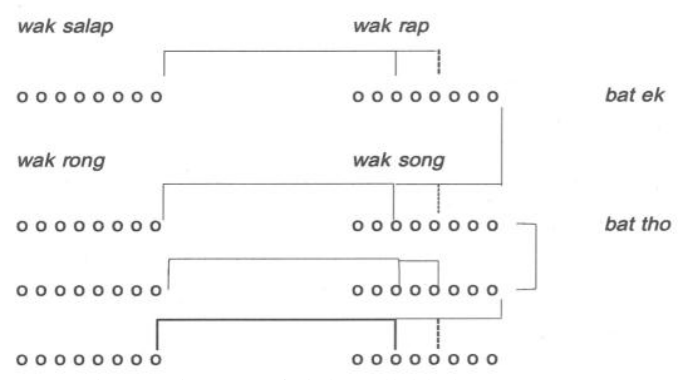

Fig. 1. Diagram of eight-syllabled poem meter. 
As in Fig. 1, the last syllable of wak salap should rhyme with the third syllable of wak rap, if it cannot be created, then the fifth syllable of wak rap can rhyme with the last syllable of wak salap. The rhymes continue in bat tho (the second line) where the last syllable of wak rap rhymes with the last syllable of wak rong and the last syllable of wak rong should rhyme with the third syllable of wak song, likewise, if the rhyme cannot be created, the last syllable of wak rong can rhyme with the fifth syllable of wak song. This is a set of desirable rhymes for one bot (stanza). The rhymes between stanzas continue through the last word of wak song which has to rhyme with the last word of wak rap in the following stanza.

There are two important phonic features in Thai poetry, internal and external rhymes, whose meanings are different from assonance and alliteration in English poetry. The phonic feature 'assonance' is the recurrence within words occuring next to or near one another of the same sound or sound-cluster in English. In Thai poems, only the same sound, not sound-cluster, is considered to be assonance. For this reason, the underlined syllables in the transliterated version of the first hemistich, si si wan $\underline{\text { ni roek }} \underline{\mathrm{di}}$ laeo, are the rhyming of the stressed vowel ' $i$ '. On the other hand, in English poems, the resemblance of sound between syllables of nearby words, arising from the use of identical consonants with different vowels is considered to be assonance. The assonance in the first hemistich is called internal rhyme in Thai poetry. In ST poetic convention, internal rhyme is categorized into consonant rhyme and vowel rhyme. In the first hemistich, si and si begin with the same consonant, thereby creating a consonant rhyme. This consonant rhyme is a poetic element called alliteration in English poetry. Another important poetic element in Thai poetry is external rhyme, rhymes between hemistiches, and the external rhyme has to be a vowel rhyme only.

The first external rhyme pair in the second segment is the last syllable of the first hemistich, laeo, and the fourth syllable of the second hemistich, kaeo. The series of external rhymes continues: the last syllable of the second hemistich, nai, rhymes with the last syllable of the last word of the third hemistich, jai, and the fifth syllable of the fourth hemistich, thai. This pattern of external rhyme is repeated in the second stanza as well. The chosen sounds (vowel rhymes) are different but the pattern remains consistent throughout. The chosen sound is ' $a$ ': the last syllable of the first hemistich of the second stanza (or the fifth hemistich of the second segment), $m a$, rhymes with the first syllable of the second hemistich of the second stanza (or the sixth hemistich of the second segment), $y a$. The last sylllable of the second hemistich of the second stanza has to rhyme with the last syllable of the previous stanza, therefore, the sound has to be 'ong', in this case, the word thong in $e k$ tone (there are five tones in Thai language and $e k$ tone is the second tone) is chosen because it rhymes with thong in saman tone (the first tone in Thai), both words are underlined twice and these are the rhymes between stanzas. The sound ong has to continue to rhyme with the last syllable of the following hemistich and the poet chooses the word thong in saman tone so the poet uses the same word which means gold twice. The word thong then rhymes with the word khong, the second syllable of the last hemistich.
The only two pairs of rhymes that can be created strictly according to the meter are the rhymes between the third hemistch and the fourth hemistich, jai (the last word of the third hemistich) and thai (the fifth word of the fourth hemistich) and thong in saman tone (the last word of the fourth hemistich) and thong in $e k$ tone (the last word of the sixth hemistich).

\section{ANALYTICAL MODEL}

Hervey and Higgins's schema of textual matrices is a top-down approach, taking text-type and context as starting points for discussing translation problems and strategies. The five matrices of features are proposed to help the translator ask and answer a series of questions that apply to any text given for translation [3]. The relevant matrices for the analysis of the second segment are formal matrix (at phonic/graphic level), cultural matrix and semantic matrix since the other two (genre matrix and varietal matrix) are not at all or as pertinent.

\section{MATRIX OF FEATURES}

\section{A. Formal Matrix}

Hervey and Higgins propose six layers of textual variables which are at phonic/graphic level, prosodic level, grammatical level, sentential level, discourse level, and intertextual level. The relevant textual variable for the second segment is at phonic/graphic level which deal with layout.

The source poem employs klon pat meter. The second segment is a target text that has the attributes of a poem. The translators have recreated in English the source poem's semantic content and its poetic form by not mimicking the source poem's patterning or a mimetic form in which the translator imitates the form of the original as best he/she can [4]. This approach is a form-derivative form, determined by the principle of seeking "some kind of equivalence in the target language for the outward form of the original poem". The translators have chosen an analogical form, also a form-derivative form. According to Holmes, the translators who make use of this form look to the function of the original poem's form within its poetic tradition, then seek a form that fills a parallel function within the poetic tradition of the target language. The example Holmes refers to is The Odyssey, an epic, and the translators belonging to this school argue that an English translation should be in verse form appropriate to the epic in English, which is blank verse or the heroic couplet.

The translators' decision to render certain segments into blank verse form may have been subconsciously influenced by what they saw in Fitzgerald's translations that Baker (one of the translators) enjoyed reading though the translators did not verbalize this in the interview ${ }^{1}$.

Before discussing the poem's phonic features in detail, I will first discuss the texts at graphic level. In the source poem, two hemistiches form one line while in the target poem, the line-break occurs after each hemistich is rendered as following:

\footnotetext{
${ }^{1}$ Unpublished. I interviewed the translators on $29^{\text {th }}$ January 2014 and the transcription will be published as a part of my $\mathrm{PhD}$ dissertation in 2016.
} 
ST layout:

ศรีศรีวันนี้ถกษ์ดีแล้ว เชิญขวัญพลายแก้วอย่าไปไหน

ขวัญมาอยู่สู่กายให้สบายใจ ชมจ้างม้าข้าไททั้งเงินทอง

TT layout:

On this sacred and auspicious day

We call on the soul of Phlai Kaeo not to stray

Oh soul, stay with this body for joy and health

Enjoy elephants, horses, servants, and wealth

Hervey and Higgins point out that readers take little notice of the shapes of what they read, paying attention primarily to the message of the utterance, for this reason, the shapes are usually irrelevant to the message. I argue that for this segment, the shape or the TT's layout is pertinent. The shapes of the message Baker and Pasuk have chosen yield different visual effects. They have translated the first segment by mimicking the eight-syllabled poem's layout while they have rendered the second segment, the one in discussion, by not mimicking the ST's poetic form, an analogical form, that is. Purely on the visual level, the switch from prose into verse from time to time in the translation automatically forces the readers to take notice of the shape of what they read.

The translators' decision to render these two segments into poetic forms reflects two different approaches to translating Thai poetry. The first segment is an attempt to replicate klon pat (eight-syllabled poem) in the TT, a mimetic form, thereby introducing a foreign element to the English readership. The second segment is an attempt to recreate a poem using different recurrent sounds and line-break that are not completely unfamiliar to the TT readers at graphic level. For instance, the line-break after each translated hemistich looks similar to the layout in The Odyssey translated by Fitzgerald. A sample of Fitzgerald's translations is as following:

But tell me this now, make it clear to me: You must be, by your looks, Odysseus' boy? The way your head is shaped, the fine eyes - yes, how like him! We took meals like this together many a time, before he sailed for Troy with all the lords of Argos in the ships. I have not seen him since, nor has he seen me' [5].

As Holmes points out that some translators believe that the verse appropriate to the epic in English is blank verse, as shown in Fitzgerald's translation of The Odyssey. Holmes states that the effect of the analogical form is to bring the original poem within the native tradition, to 'naturalize it'. The interesting point that Holmes raises is that:

The analogical form is the choice to be expected in a period that is inturned and exclusive, believing that its own norms provide a valid touchstone by which to test the literature of other places and other times. Periods of this kind tend moreover to have such highly developed genre concepts that any type of form other than the analogical would be quite unacceptable to the prevailing literary taste.

Sepha rueang Khun Chang Khun Phaen was translated into English prose in two volumes by Prem Chaya (Prince Prempurachatra) in 1955 and 1959 in an abridged version. This Thai literature from around 1500 had not been tested until the complete translation by Baker and Pasuk was published in 2010. It is debatable whether the twenty-first century is the period where a Thai poetic form would be acceptable to the English readership. Firstly, the analogical form is used more than the mimetic form because it poses fewer translation constraints. Secondly, the whole story is mostly translated into prose, therefore this Thai epic is not being put to the test, to arrive at a translation norm, to the extent that Homeric works have been several times. The decision to translate the Thai klon pat verse form into an analogical form of English verse may not be directly linked to 'highly developed genre concepts' in the English language. It may sound too simplistic a reason but still rings true; the differences in phonological rules, morphological patterns and syntactic rules between Thai and English make the task of transferring both the message and effects of the message upon the receiver quite difficult.

The ST shape is not a source of textual effects; it does not make use of the visual effects on the graphic level. By contrast, the TT shape is a source of textual effects; when the translated text is presented in poetic forms, it stands as a reminder that the source text is composed in traditional Thai verse, not prose. The TT readers are also presented with poetic elements, such as assonance, alliteration and rhymes, which are the properties of Sepha rueang Khun Chang Khun Phaen from the beginning to the end.

After looking at the second segment as a sequence of letters, or graphically, I will now examine the text as a sequence of sound-segments. Written texts are more often considered phonically than graphically from a translation point of view, point out Hervey and Higgins, who add that readers tend to notice repetition of sounds, correspondingly the translators of literary STs should pay attention to marked phonic features because of their thematic and expressive functions.

There are two phonic features in Thai poetry, internal and external rhymes. I pinpoint (same-sound) assonance as a marked phonic feature because the translators have retained this feature in the TT as shown (underlined) in the translation of the whole second segment:

\section{On this sacred and auspicious day}

We call on the soul of Phlai Kaeo not to stray

Oh soul, stay with this body for joy and health

Enjoy elephants, horses, servants, and wealth

Oh soul, please come along and see

Don't go hunting and wandering aimlessly

Come and enjoy garlands of crystal and gold

An abundance to make your happiness unfold.

Rhyme, the coincidence of sounds, is closely bound to verse design or meter. It is presumed up to this point that the translators rendered the TT into blank verse form. Lennard notes that blank verse, the best-known and most influential form in English is the unrhymed iambic pentameter [6]. Blank verse is composed to sound as close as everyday speech. Five feet make up one line and the basic foot is an iamb, which is an unstressed beat followed by a stressed beat. Lennard remarks that because iambic metres (rhythmic patterns) sound most like ordinary speech, they are therefore most popular with poets. Lennard states that all lines conform 
exactly to the prescribed metrical pattern only in boring poems. A sequence of completely regular lines would sound monotomous and artificial. This is where Thai and English prosodic conventions diverge. Thai poets are considered skilled only when all their lines conform exactly to the prescribed metrical pattern. It is, therefore, not difficult to decide what the meter of the Thai poem is because of the absence of variability and irregularity. In this TT, the variability and irregularity can be seen from the use of different line lengths (tetrameter and pentameter feet per line) and the use of different base feet (iamb, trochee and dactyl). To draw a conclusion from this segment alone, it can be said that the pattern of five iambs is not the template the translators could strictly use to transfer both poetic effects and meanings to the English readership. To be able to conclude that blank verse is the template the translators modified, all the segments that are rendered into verse in the translation The Tale of Khun Chang Khun Phaen have to be analyzed.

Regarding the kind of rhyme used in the TT, four lines make a quatrain and the TT is couplet-rhymed quatrains. The rhyme-scheme is aabb (day/stray, health/wealth). Fussell [7] affirms that the essential element of coherence in a stanza is end-rhyme, in spite of the fact that lines can be organized into stanzas without it. End-rhyme has developed into a convention because the part that is the most emphatic is the end of poetic line. Even if the end of the line offers the reader no rhyme, the end of the line constitutes an accumulation of forces. In this segment, the words ending the lines rhyme. All rhymes, except 'see-aimlessly', are full rhymes (which occur when two or more words or phrases share the same last stressed vowel and all following sounds). The end-rhyme 'see/aimlessly' is a half rhyme (where either the stressed vowel or following sounds differ).

It is rarely possible to produce a TT which can retain all ST poetic elements and if that were to happen, sacrifice of literal and connotative meaning would occur. Assonance, or external rhyme according to Thai poetic convention, is saved in the TT so as to not sacrifice all the effects in this segment.

\section{B. Cultural and Semantic Matrix}

I combine cultural and semantic matrices together and discuss culturally specific items, their meanings and also meanings of other words pertaining to translation shifts in this one combined matrix.

In terms of cultural matrix, Hervey and Higgins define culturally relevant features as the features which are specific to source language and the source culture and which make the ST what it is. They offer only a summary of translation procedures for these features, which are exoticism, calque, cultural borrowing, communicative translation and cultural transplantation. These procedures will be compared with procedures proposed by others.

Regarding semantic matrix, Hervey and Higgins state that literal meaning of a word is only one aspect of meaning and connotative meanings form part of its overall meaning. They categorize connotative meanings into six types: literal meaning, allusive meaning, attitudinal meaning, associative meaning, collocative meaning, reflected meaning and affective meaning. I will refer to connotative meanings of a word whenever their presence in context is felt.

In order to discuss the translation of culturally specific items, the concept of equivalence cannot be ignored. Hervey and Higgins disagree with three-valued view that equivalence implies sameness, 'gain' implies a plus value and 'loss' a minus value. They propose a two-valued system (loss $\sim$ no loss) in which the notion that translation loss is inevitable and that even so-called gain is a loss. Both argue that because source language and target language are fundamentally different, the transfer from ST to TT inevitably imposes difference or loss. These two assert that if translation loss is inevitable, the challenge to the translator is to control and channel it by deciding which features in a given ST are most important to respect and which can most legitimately be sacrificed in respecting them. The authors recommend the translators "to look, not for what is to be put into the TT, but for what might be saved from the ST". Hervey and Higgins justify their proposed system by adding that the belief in gain lead the student translators to add or alter detail, hoping that the losses will be outweighed by a greater volume of gains.

Other scholars hold various views towards the concept of equivalence. Baker [8] states that equivalence can be obtained to some extent but it is influenced by a variety of linguistic and cultural factors and is therefore always relative. Nord [9] clarifies the Skophostheorie's stance on equivalence, explaining that to achieve equivalence, the TT has to serve the same communicative function or functions as the ST while Snell-Hornby [10] posits that the concept of equivalence is general, abstract, and unsuitable as a basic concept in translation theory because:

The term 'equivalence' presents an illusion of symmetry between languages which hardly exists beyond the level of vague approximations and which distorts the basic problems of translation.

The system proposed by Hervey and Higgins is appropriate for translator-training. I believe that the three-valued view is suitable for explaining the translation of words in context since equivalence has to be gauged and when meaning is distorted, it is either something is being added to or taken out of that word. For this reason, I agree with Baker and I strongly disagree with Snell-Hornby because without aiming for symmetry, further criteria to judge a translation have to be proposed. I partly agree with Nord. Communicative function or functions of a poem can be modified by the translator, therefore, the function(s) the ST has might not necessarily be one(s) that the TT will have. For instance, the translators of Sepha rueang Khun Chang Khun Phaen seem to want to elevate the status of this Thai classic through their English translation, that being the case, their translation decisions seem to be guided by this self-imposed mission. However, this issue will not be dealt with in this paper. The function(s) of the ST and the TT will not always be one and the same. Even when the TT serves the same communicative function(s) as the ST, this in itself does not supply concrete translation procedures/strategies.

I will discuss six translated choice. Because of differences in sentence constructions between Thai and English, some of these choices are presented in a table.

\section{1) The word "ศรี" ( $\mathrm{si}$ )}

As seen in Table I, there are seven syllables in the first hemistich, the first two have been omitted in the TT. The 
third syllable wan, literally meaning 'day' and the fourth syllable $n i$, a demonstrative modifier, literally meaning 'this/these', have been rendered literally in the TT. The meaning and signifance of the fifth syllable, roek, will be explained when it is examined.

\begin{tabular}{c|c}
\multicolumn{2}{c}{ TABLE I: THE FIRST HEMISTICH } \\
\hline ST & ศรีศรีววนนี้ถกษ์ษีแล้ว \\
\hline Transliteration & si si wan ni roek di laeo \\
\hline Literal translation & Prosperity, this day the roek is good \\
\hline TT & On this sacred and auspicious day \\
\hline
\end{tabular}

There is no trace of the words $s i$ si, which is a reduplication in TT. The root is repeated and is employed to add plurality to a word. $S i$ as a noun means prosperity, betel leaf, woman, and in poetry person [11]. $\mathrm{Si}$ is also used as a prefix in front of a name to show respect. In this hemistich, si most likely means 'prosperity' and it is pronounced twice, presumably because being successful in material terms is desirable and it is considered auspicious to use as many positive words in this type of ceremony.

The translation of the first hemistich contains six words, which is not yet weighty compared to the number of syllables employed in the ST (seven syllables). This lexical loss cannot be justified by the constraint imposed by eight-syllabled poem's governing meter because the translators decided to opt for an English verse form; the number of words/syllables is not confined to eight to nine syllables in one hemistich. Translation loss may be inevitable, but in this case, it seems that the loss can be avoidable.

\section{2) The word “ฤกษ" (roek)}

There is no standard communicative equivalent of the word roek (ฤกษ์), a culturally specific item. The fifth syllable of the first hemistich (refer to Table I), roek, is modified by an adjective $d i$ (the sixth syllable in the transliteration column), literally meaning 'good'. Roek di have been rendered as adjectives, roek as 'sacred' and $d i$ as 'auspicious'.

The ST readers know that roek has to be found by consulting experts or handbooks about roek. Finding roek is a predictable pattern of shared practices. If a Thai couple plan to get married, their parents will ask if they have sought for roek and if they have not and plan not to, they will be reprimanded and forewarned about many negative consequences. If indeed this couple's wedding ceremony goes wrong or their marriage does not last long, it will become the story that will be told and retold as an advice to seek roek before holding any major rituals. Seeking roek is the accepted way of doing things in Thai culture.

After receiving good roek and/or bad roek, most people usually oblige by organizing an event on a particular day or avoiding particular days as recommended. The siginificance of roek di is lost on the English readers. The English version reveals to the TT readers only that it is a sacred day for a ceremony to be performed, it does not pertain to the knowledge where the sacredness comes from, assuming that sacredness is a feature of roek.

According to the Royal Institute Dictionary B.E. 2542, roek is a noun, borrowed from Sanskrit. A complete definition is "the time that is fixed or is expected to yield good result(s), such as, good roek and bad roek. It is usually used with happy events, for instance, finding roek for wedding".

The translation of roek $d i$ as 'sacred and auspicious day' is the kind of translation that has opted for naturalness at the expense of accuracy. For this reason, connotative meaning(s) that roek may carry will be discussed. To the translators, roek (presumably) contains associative meaning which is an expression consisting of expectations which are rightly or wrongly associated with the referent of the expression. There is a widespread positive attitude towards the professionals who can give roek. Some Thai people seek advice from monks, Bhramin astrologers, or Chinese astrologers about when to hold a wedding ceremony, build a house, or start a new business. Without the respect for certain monks or astrologers, people would not seek them out. It is to be presumed for this reason that roek that one obtains from an expert, based on his knowledge, is thereby sacred. However, the definition of roek cited earlier does not denote the quality of sacredness, only that of auspiciousness.

To provide the overall meaning of an expression roek $d i$, the translators have used compensation. In this case, the translators' choice 'sacred and auspicious day' is a product of literal meaning and assumed connotative meaning. 'Sacred' is added to describe the fixed time to compensate for the fact that roek di has to be given by a learned person or sought from manuals. The translators have combined literal meaning and assumed connotative meaning in producing what they hope to be the overall semantic impact.

This translation choice 'sacred and auspicious day' is not a choice that is source-culture oriented. It is neither situationally equivalent nor culturally analogous in the sense that the same situations or functions cannot be identifed in both cultures; the concept of roek does not exist in the western society/culture.

According to Dickins [12], Hervey and Higgins' 'communicative translation' could be regarded as identical to Newmark's 'functional equivalence' which is interpreted as what is functionally appropriate in a given situation. For this reason, to describe the translation of the word roek, Newmark's 'descriptive equivalent' is a more precise translation procedure. This procedure involves a precise description of what is meant by the source culture element through the use of words and phrases generally understood in the target culture. The words 'sacred and auspicious day' are culture-neutral description which fail to provide a complete description of roek. On the one hand, these words represent a briefer definition (of roek) than the ST usage. On the other hand, these translated words are a result of textual expansion; an additional word 'sacred' is used; additional information, which is not in the source text, is added in the target text.

\section{3) The word “ขวัญ” (khwan)}

Tambiah explains that khwan is a Thai word connoting spiritual essence connected with the human body [13]. He asked the villagers about the characterization of khwan and they told him that khwan resides in the human body and can leave its owner's body when he or she is frightened, sick, or in trouble. When khwan flees the body, the owner is exposed to suffering, illness and misfortune. The causes and 
consequences of khwan's departure are formulated in a circular manner: when khwan flees the body, it will result in sickness then the ceremony must be held to prevent the flight or sickness of the body can lead to agitation of the mind and khwan's flight, for that reason, khwan must be called back. The rite called 'su khwan' (calling the khwan) is performed by elders for their youthful successors by calling the khwan and binding it to the body of its owner by tying a piece of thread to his or her wrist.

Tambiah notes that some writers have rendered khwan as 'life soul' and 'benevolent guardian spirit of an extremely ephemeral essence' while he himself uses the transliterated form ' $k$ hwan' and gives his translation as 'spirit essence'.

Since the concept of khwan does not exist in the West, khwan then has to be equated with something that does exist and 'spirit', with its Christian association, seems to be the choice that is most close to khwan. The translators, however, have not used 'spirit' when khwan is referred to. They have chosen 'soul', the word and the concept with Christian association. The meanings of 'soul' will then be presented and compared with the meanings of khwan.

There are two definitions of 'soul' in Collins English Dictionary [14] which are relevant: '1) the spirit or immaterial part of man, the seat of human personality, intellect, will and emotions, regarded as an entity that survives the body after death and 2) Christianity the spiritual part of a person, capable of redemption from the power of sin through divine grace'. There are two noticeable elements from these definitions, the word 'Christianity' and the concept of immortality. If soul is taken to mean the spiritual or immaterial part of a human being regarded as immortal then khwan cannot be equated with soul, because when the person dies, khwan dies too.

When the translated choice 'soul' is first presented in the translation, it is accompanied by the footnote as following:

ขวัญ, khwan, sometimes translated as spirit essence or life essence. In Thai traditional belief, the body and its various elements, usually numbered as thirty-two, all have a khwan or spiritual representation. In cases of illness or psychological trouble, the khwan is believed to have deserted the body for some reason. The ceremony of riak khwan, or soul calling, is performed for a wide range of occasions, including illness, travel, and life-cycle ceremonies such as birth and marriage.

The footnote can be used to add information which may be useful in understanding the cultural background of the TT. In the footnote, the translators offer the transliterated form of the TT and other translated choices ('spirit essence' and 'life essence'), however, their final choice 'soul' is not supported by further explanation. Sometimes footnoting can help inform translation procedure(s). In this case, it is not clear why a cultural transplantation procedure is preferred.

The translators have substituted 'soul' in the target text from the target culture because the same elements are not found in both cultures. It can be said that this translation choice is target-culture oriented because the word that is indigenous to the target language and the target culture is preferred. The result is that foreignness is reduced. To some extent, khwan, which is culturally transplanted by 'soul', has been naturalized into the target language and its cultural setting.

4) The words “พวงแก้วและพวงทอง” (phuang kaeo lae phuang thong)

These words are used in the seventh hemistich. The word phuang is a shortened form of the words phuang malai which literally mean 'lei of flowers' [15]. To ascertain whether or not this translation choice is a literal translation, the items used in the ceremony organized to call khwan back have to be examined. The item called bai si (บายศรี) is used in khwan-calling ceremony. It is made of banana leaf. The leaf is folded to create a cone and a boiled egg is placed on top of the cone, and the flowers, usually jasmine, strung along a thin stick, is deposited on top of the boiled egg [16]. Other items surrounding the cone are three pieces of banana, three pieces of cucumber, and sometimes foi thong (a sweet, made of eggs, drawn into thin strands and boiled in sugar syrup). Other flowers are also used to decorate the bai si but the types of flowers are not specified.

The words phuang kaeo lae phuang thong (lae means 'and') might not be as straightforward as the TT suggests. This culturally specific item phuang kaeo lae phuang thong is rendered literally because this term is also unclear in the ST. The ST readers are familiar with garlands made of flowers and leaves, which are used as an offering to the Buddha and other Gods or ghosts they pay respect to. Garlands that are made of crystal and gold are not common items. They might be just normal garlands but the words kaeo and thong are added because of their positive meanings, especially in the ceremony that regards khwan as an important part of any human being. The translated choice 'garlands of crystal and gold' to an extent brings an exotic quality to this item. The word 'garland' is not unheard of in the English-language world but the image 'garlands of crystal and gold' creates might mislead the TT readers to think that these garlands are used in the actual khwan-calling ceremony, when it is just another term to call 'garlands made of flowers and leaves' in the ST setting.

5) The words “เจ้า" (jao) and “พ่อ” (pho)

\begin{tabular}{c|c}
\multicolumn{2}{c}{ TABLE II: THE FIFTH HEMISTICH } \\
\hline ST & ขวัญเอ๋ยเจ้ามาเถิดพ่อมา \\
\hline Transliteration & khwan oei jao ma thoet pho ma \\
\hline Literal translation & Khwan, prithee, you, come, please, father, come \\
\hline TT & Oh soul, please come along and see \\
\hline
\end{tabular}

These two words are found in the fifth hemistich as can be seen in Table II. The underlined words jao (เจ้า) and pho (พ่อ) are pronouns in this hemistich. There is a large inventory of personal pronouns in Thai and different terms are distinguished by the level of formality and the referent's sex [17]. Many personal pronouns can function as first-person and second-person pronouns, second-person and third-person pronouns and third-person and first-person pronouns.

According to the Royal Institute Dictionary B.E. 2542, jao, as a second-person pronoun, is used by an older person to refer to a younger person in a polite way. It is also used as a third-person pronoun with a deictic nan (meaning 'that') as jao nan, meaning 'that (younger) person'. 
According to the Royal Institute Dictionary B.E. 2542, pho means the man who gives birth to a child. It is a word used by a child to refer to the person who gives birth to him/her or brings him/her up. In addition, the older person refers to a younger person he/she is close to as pho. It is also used to precede the male leaders, such as pho mиeang (the ruler of the town).

In the case of jao, it is only an addressee reference term while certain kin terms, such as pho (father) or mae (mother), are used in the real family structure as a first-person or a second-person reference term. In this context, pho does not mean father. Furthermore, pho is strictly used to refer to male referents while jao refers to both male and female.

One of cohesive devices in English is cross-reference [18]. It may be a device for either a repetition of meaning or for a repetition of reference and repetition is expressive in that it gives emphasis or emotive heightening to the repeated meaning. This also applies to Thai language. In the case of the fifth hemistich, khwan (underlined twice) is the main entity (for lack of a better word) being called upon and jao and pho are both personal pronouns, used so close to the thing they refer to, for emotional appeal. They are used closely together in this hemistich to persuade khwan of Phai Kaeo (the childhood name of Khun Phaen) to return. The khwan of a person is treated as a person, belonging to the same sex of that person. The translation of the fifth hemistich treats khwan as a spiritual representation through the word 'soul' but the calling verbalized by the older person to the younger person through the pronoun jao and the association of khwan with the male sex through the word pho are lost on the TT readers.

$$
\text { 6) The word "กะเกณฑ์" (ka-ken) }
$$

\begin{tabular}{c|c}
\multicolumn{2}{c}{ TABLE III: THE SIXTH HEMISTICH } \\
\hline ST & อย่าเที่ยวกะเกณฑ์ตระเวนท่อง \\
\hline Transliteration & thiao $\underline{\text { ka-ken }}$ tra-wen $\underline{\text { thong }}$ \\
\hline $\begin{array}{c}\text { Literal } \\
\text { translation }\end{array}$ & $\begin{array}{c}\text { Don't travel, be compelled to wander and wade in } \\
\text { water }\end{array}$ \\
\hline TT & Don't go hunting and wandering aimlessly \\
\hline
\end{tabular}

As shown in Table III, the word ka-ken is used in the sixth hemistich. Based on the Royal Institute Dictionary B.E. 2542, 'ka-ken' means 'to oblige, require'. Damnern and Sathienpong [19] translate ka-ken' in their Thai-English Dictionary as 'to conscript, force, compel'.

The word 'ka-ken' rhymes with the word 'tra-wen' or what is called a vowel internal rhyme in Thai poetry. The word ' $y a$ ' means 'do not' and it is followed immediately by four verbs thiao, ka-ken, tra-wen and thong as underlined in both ST and transliteration columns. Thai verbs can be strung together without an overt linking word to form a serial verb construction. The word thiao can be used to modify the verb that follows it immediately: it modifies the verb ' $k a-k e n$ ' (to compel), together they mean 'keep compelling'. The literal meaning of tra-wen is to wander and the literal meaning of thong is to wade through water.

Ka-ken possesses meaning in its own right but the position of this word in this hemistich does not lend itself any meaning. Substituting individual words with their dictionary equivalents will not lend the whole hemistich much sense. Ka-ken tra-wen is not the collocational patterning in the ST. It is not a marked collocation, which is an unusual combination of words, one that challenges our expectations as readers, often used in poetry to create unusual images, produce laughter, and catch the reader's attention. Most likely this word ka-ken is only used to create an internal rhyme.

Ka-ken cannot be equated with 'hunting' because khwan is known to flee the body and wander but for khwan to go hunting, it is never heard of. Translating ka-ken as 'hunting' (underlined twice in the TT column) does not accurately render the literal meaning of the ST either. This choice reflects the translators' attitude to khwan, in the way that khwan is understood to be predator-like. It can be said that the translators have tried to create a rhyme, 'hunting' rhymes with 'wandering'. However, the translators could have chosen another verb that is synonymous with 'wandering', for example, 'travelling'. After evaluating ' $k a$-ken' in context, the meaning of this word still does not stretch from 'compel' to as far as 'hunting'.

\section{CONCLUSION}

Sound clustering, characteristic word shapes and sentence constructions determine the possible verse design in the target language and the translators' product, the TT presented in this paper, reveals some variability from the prescribed metrical pattern of blank verse. The translators' attempt to render this segment into an English verse also reveals some translation shifts; meanings of the words used in the poem are omitted, added to, transplanted, translated too literally, and mistranslated.

\begin{tabular}{|c|c|c|}
\hline \multicolumn{3}{|c|}{ APPENDIX } \\
\hline $\begin{array}{c}\text { Source text }(\mathrm{ST}) \text { and } \\
\text { transliteration }\end{array}$ & Literal translation & Target text (TT) \\
\hline $\begin{array}{l}\text { ศรีศรีวันนี้ถกษ์ดีแล้ว } \\
\text { si si wan ni roek di laeo }\end{array}$ & $\begin{array}{l}\text { Prosperity, this day } \\
\text { the roek is good }\end{array}$ & $\begin{array}{l}\text { On this sacred and } \\
\text { auspicious day }\end{array}$ \\
\hline $\begin{array}{l}\text { เชิญขวัญพลายแก้วอย่าไปไหน } \\
\text { choen khwan phlai kaeo ya } \\
\text { pai nai }\end{array}$ & $\begin{array}{l}\text { Inviting khwan of } \\
\text { Phlai Kaeo not to go } \\
\text { anywhere }\end{array}$ & $\begin{array}{l}\text { We call on the soul } \\
\text { of Phlai Kaeo not to } \\
\text { stray }\end{array}$ \\
\hline $\begin{array}{l}\text { ขวัญมาอยู่สู่กายให้สบายใจ } \\
\text { khwan ma yu su kai hai } \\
\text { sabai jai }\end{array}$ & $\begin{array}{l}\text { Khwan, come back } \\
\text { to stay with the body } \\
\text { for heart's comfort }\end{array}$ & $\begin{array}{l}\text { Oh soul, stay with } \\
\text { this body for joy } \\
\text { and health }\end{array}$ \\
\hline $\begin{array}{l}\text { ชมช้างม้าข้าไททั้งเงินทอง } \\
\text { chom chang ma kha thai } \\
\text { thang ngoen thong }\end{array}$ & $\begin{array}{l}\text { To see elephants, } \\
\text { horses servants, } \\
\text { including silver and } \\
\text { gold }\end{array}$ & $\begin{array}{l}\text { Enjoy elephants, } \\
\text { horses, servants, } \\
\text { and wealth }\end{array}$ \\
\hline $\begin{array}{l}\text { ขวัญเอ๋ยเจ้ามาเถิดพ่อมา } \\
\text { khwan oei jao ma thoet } \\
\text { pho ma }\end{array}$ & $\begin{array}{l}\text { Khwan, prithee, } \\
\text { you, come, please, } \\
\text { father, come }\end{array}$ & $\begin{array}{l}\text { Oh soul, please } \\
\text { come along and see }\end{array}$ \\
\hline $\begin{array}{l}\text { อย่าเที่ยวกะเกณฑ์ตระเวนท่อง } \\
\text { ya thiao ka-ken tra-wen } \\
\text { thong }\end{array}$ & $\begin{array}{l}\text { Don't travel, be } \\
\text { compelled to } \\
\text { wander and wade in } \\
\text { water }\end{array}$ & $\begin{array}{l}\text { Don't go hunting } \\
\text { and wandering } \\
\text { aimlessly }\end{array}$ \\
\hline $\begin{array}{l}\text { มาชมพวงแก้วและพวงทอง } \\
\text { ma chom phuang kaeo lae } \\
\text { phuang thong }\end{array}$ & $\begin{array}{l}\text { Come see phuang } \\
\text { kaeo lae phuang } \\
\text { thong }\end{array}$ & $\begin{array}{l}\text { Come and enjoy } \\
\text { garlands of crystal } \\
\text { and gold }\end{array}$ \\
\hline $\begin{array}{l}\text { ข้าวของเหลือหลายสบายใจ } \\
\text { khao khong luea lai sabai } \\
\text { jai }\end{array}$ & $\begin{array}{l}\text { There are rice, many } \\
\text { things left for } \\
\text { heart's comfort }\end{array}$ & $\begin{array}{l}\text { An abundance to } \\
\text { make your } \\
\text { happiness unfold. }\end{array}$ \\
\hline
\end{tabular}




\section{ACKNOWLEDGMENT}

Gritiya thanks Prof. Jeremy Munday and Dr. Martin Seeger, her supervisors, for commenting on this section of her $\mathrm{PhD}$ work several times and her family in Thailand for unwavering support.

\section{REFERENCES}

[1] C. Baker and P. Pasuk, The Tale of Khun Chang Khun Phaen, Chiang Mai: Silkworm Books, 2010.

[2] K. Nim, Principles of Thai Language (Lak phasa thai), Bangkok: Thai Watthana Phanit, 2000, pp. 359-360.

[3] S. Hervey and I. Higgins, Thinking French Translation, 2nd ed. London and New York: Routledge, p. 2, 2002.

[4] J. S. Holmes, Translated! Papers on Literary Translation and Translation Studies, Amsterdam: Rodopi, p. 26, 1988.

[5] Homer, The Odyssey, London: Heinemann, 1962, p. 8.

[6] J. Lennard, The Poetry Handbook, 2nd ed. Oxford: Oxford University Press, 2005, p. 36.

[7] P. Fussell, Poetic Meter and Poetic Form, New York, St. Louis, San Francisco: McGraw-Hill, 1979, p. 110.

[8] M. Baker, In Other Words, London and New York: Routledge, 2006, p. 6.

[9] C. Nord, Translating as a Purposeful Activity: Functionalist Approaches Explained, Manchester: St. Jerome, 1997, p. 36.

[10] M. Snell-Hornby, Translation Studies: An Integrated Approach, Amsterdam: Benjamins, 1988, p. 22.

[11] Royal Institute, Dictionary, Royal Institute Edition, Buddhist Year 2542 (Photchananukrom chabap ratchabandittayasathan po so 2542), Bangkok: Nanmee Books, 2003.

[12] J. Dickins, "Procedures for translating culturally specific items," in Language Studies: Stretching the Boundaries, A. Littlejohn and R. S. Mehta, Eds. Newcastle upon Tyne: Cambridge Scholars Publishing, 2012, pp. 43-60.

[13] S. J. Tambiah, Buddhism and the Spirit Cults in North-east Thailand, Cambridge: Cambridge University Press, 1970, pp. 57-58.

[14] HarpersCollins, Collins English Dictionary, 8th ed. S. Anderson, J. Butterfield, J. Crozier, J. Daintith, G. Davidson, A. Grandison et al., Eds. Glasglow: HarpersCollins, 2006.
[15] S. Sethaputra, New Model Thai-English Dictionary, Bangkok: Prima Publishing, 2004, p. 286.

[16] Y. Satienkoset, The Study of Arts and Cultures (Kan sueksa sinlapa lae prapheni), Bangkok: Bannakhan, 1974, p. 261.

[17] S. Iwasaki and I. Preeya, A Reference Grammar of Thai, Cambridge: Cambridge University Press, 2005, p. 49.

[18] G. Leech and M. Short, Style in Fiction: A Linguistic Introduction to English Fictional Prose, London and New York: Longman, 1981, p. 244.

[19] G. Domnern and W. Sathienpong, Thai-English Dictionary (Revised B.E. 2549), 3rd ed. Bangkok: Matichon Publishing House, 2006, p. 24.

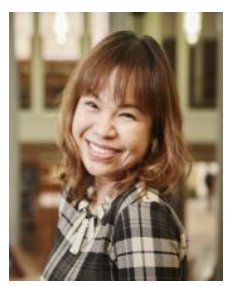

Gritiya Rattanakantadilok was born in Songkhla, Thailand on April 30, 1982. She received her B.A. degree in political science, from Chulalongkorn University, Bangkok, Thailand in 2005. Then she got her M.A. degree in translation and interpretation, from Chulalongkorn University, Bangkok, Thailand in 2009.

She is currently a $\mathrm{PhD}$ candidate at the School of Languages, Cultures and Societies, University of Leeds, UK. She taught translation at the Faculty of Liberal Arts, Prince of Songkla University, Thailand, from 2009 to 2012 and will return to the same position after completing her $\mathrm{PhD}$ degree. Some of her published papers are: "Thai folk epic: Victorian much?" presented at the $5^{\text {th }}$ Annual University of Leeds Postgraduate Researcher Conference, December 2014; "Explicit grammar teaching in translation," presented at the 1st International Conference on Translation and Interpretation: Translation and Interpretation in a Multilingual Context, Bangkok, Thailand; "Book review: The golden notebook by Doris Lessing," Journal of European Studies, vol. 16 , no. 1, pp. 146-178, 2008. Her research interests are teaching translation, translation of traditional Thai poetry and gender in translation.

Gritiya Rattanakantadilok received a full sponsorship, the Humanity and Social Science Scholarship of Thailand, granted by the Office of Higher Education Commission, Ministry of Education, to pursue a $\mathrm{PhD}$ degree in translation studies at University of Leeds from 2012 to 2016. 